\title{
KUALITAS PELAYANAN IZIN MENDIRIKAN BANGUNAN (IMB) \\ PADA BADAN PELAYANAN PERIZINAN TERPADU DAN PENANAMAN MODAL (BPPTPM) KABUPATEN CIANJUR PROVINSI JAWA BARAT
}

\author{
SERVICE QUALITY ON BUILDING PERMIT AT ONE STOP \\ PERMIT SERVICE AND INVESTMENT BOARD (BPPTPM) OF \\ CIANJUR REGENCY WEST JAVA PROVINCE
}

\author{
Nanang Suparman \\ FISIP UIN Sunan Gunung Djati Bandung \\ Jln. A.H. Nasution No. 105 Bandung 40614 \\ Email: n.suparman69@gmail.id.com.
}

Naskah diterima: 21 Februari 2017, revisi pertama: 1 Maret 2017, revisi kedua: 21 April 2017, revisi ketiga: 19 April 2017, disetujui 21 April 2017.

\begin{abstract}
Public should receive an easy, fast, accurate, and secured services in getting any licenses they need. In order to that, the purposes of this research are to understand how the issue of building permit process is done, reveal the meaning of the whole phenomenon according to the public and the Government, and to know the obstacles or problems faced by BPPTPM Cianjur in West Java as the unit in charge of licensing areas. This research applied descriptive study with qualitative approach. From the results of the analysis, it could be concluded that the quality of licensing which is measured through four (4) dimensions: easiness, speed of service, accuracy, and security had not been going well yet. It happened because of some factors such as: unsolid organizational structure, imbalances of human resources in both quantitative as well as qualitative, inadequate and out of date infrastructure and technology, and complicated procedure.
\end{abstract}

Keywords : BPPTPM, IMB, Quality of Service

\begin{abstract}
Abstrak
Dalam mengurus perizinan, publik seharusnya menerima pelayanan secara mudah, cepat, tepat, dan aman. Tujuan penelitian ini adalah untuk memahami bagaimana proses pelayanan perizinan mendirikan bangunan dilakukan dan mengungkap makna pelayanan menurut publik dan pemerintah dan mengetahui kendala atau permasalahan yang dihadapi BPPTPMKabupaten Cianjur Jawa Barat sebagai penanggung jawab bidang perizinan.Jenis penelitian ini deskriptif dengan pendekatan kualitatif. Dari hasil analisis menunjukkan bahwa kualitas perizinan mendirikan bangunan yang diukur melalui 4(empat) dimensi yakni dimensi kemudahan, dimensi kecepatan, dimensi ketepatan, dan dimensi
\end{abstract}


keamanan cenderung belum berjalan baik,hal demikian terjadi akibat faktor-faktor kendala yang mempengaruhi antara lain struktur organisasiyang belum solid, ketimpangan sumber daya manusia baik kuantitatif maupun kualitatif,daya dukung infrastruktur dan teknologi perkantoran yang kurang memadai dan tidak up to date, dan kerumitan prosedur yang belum terurai.

Kata kunci: Kualitas Pelayanan, IMB, BPPTPM

\section{A. PENDAHULUAN}

Pemerintah Daerah Kabupaten CianjurJawa Barat dalam rangka melayani permohonan masyarakat di bidang perizinan mendirikan bangunan (IMB) membentuk Badan Pelayanan Perizinan Terpadu dan Penanaman Modal (BPPTPM) melalui Peraturan Daerah (Perda) Kabupaten Cianjur Nomor 12 Tahun 2005 tentang Organisasi dan Tata Kerja BPPTPM.

Berdasarkan kewenangan yang telah diserahkan kepada BPPTPM, maka terdapat jenis perizinan dan Non Perizinan yang dikeluarkan oleh BPPTPM, yaitu jenis pelayanan perizinan termasuk Izin Bangunan (IMB) danjenis pelayanan non perizinan, dimana dalam pelaksanaannya tetap dikoordinasikan dengan unit kerja pengelolanya masing-masing. Tujuan utama dikeluarkannya IMB adalah sebagai instrumen pengendalian dan pemanfaatan ruang, pengendalian kelayakan bangunan, kepatuhan pada perundangan, dan penyederhanaan pelayanan.

Pada beberapa Kecamatan di Wilayah Kabupaten Cianjursebelah utara yang meliputi Kecamatan Cipanas, Pacet, Cimacan, Sukaresmi, dan Ciloto tumbuh secara alami sebagai daerah tujuan wisata bernuansa pegunungan sebagai bagian dari kawasan wisata Puncak. Kepariwisataan dicirikan oleh antara lain pesatnya pembangunan fisik berupa sarana objek wisata, hotel, bungalow, vila, maupun perumahan. Pada satu sisi kawasan Puncak dan sekitarnya adalah kawasan hijau dan resapan air harus dilindungi dari maraknya pembangunan fisik terutama yang tidak mengantongi IMB. Kontradiktif dalam pengelolaan pengembangan kawasan Puncak menuntut ketegasan Pemerintah Daerah Cianjur terhadap pihak-pihak yang melanggar ketentuan perizinan, dan sebaliknya Pemerintah daerah melalui BPPTPMharus memberikan kemudahan kepada masyarakat yang telah menempuh prosedur yang benar dalam pengurusan perizinan termasuk IMB.

Tabel 1.

Jenis IMB Kabupaten Cianjur

\begin{tabular}{|c|c|c|c|c|c|}
\hline \multirow{2}{*}{ Tahun } & \multicolumn{5}{|c|}{ Jenis IMB } \\
\cline { 2 - 6 } & R. Tinggal & Villa & R. Usaha & Perumahan & Perkantoran \\
\hline 2012 & 214 & 312 & 267 & 86 & 213 \\
\hline 2013 & 198 & 201 & 155 & 92 & 104 \\
\hline 2014 & 216 & 322 & 176 & 98 & 125 \\
\hline 2015 & 265 & 350 & 212 & 102 & 132 \\
\hline
\end{tabular}

Sumber: BPPTPM, 2017 (diolah)

Namun demikian dalam realitasnya, masih saja ditemui adanya berbagai kritikan dan keluhan masyarakat terhadap pelayanan publik yang diberikan oleh Instansi Pelayanan Perizinan Terpadu, dimana hal ini tentu akan sangat berpengaruh terhadap citra Pemerintah di mata masyarakat. Di Kabupaten Cianjur sendiri pelayanan Izin Mendirikan Bangunan masih menjadi keluhan publik 
umumnya melalui media massa sebagaimana diterangkan oleh Kabar Cianjur (2015) menyatakan bahwa berdasarkan keluhan warga bahwa Badan Pelayanan Perizinan Terpadu dan Penanaman Modal (BPPTPM) dalam memberikan pelayanan perizinan kepada masyarakat masih terdapat praktek rente di luar yang telah diatur dalam Peraturan Daerah. Masyarakat kesulitan memahami dan mengikuti pola baru layanan perizinan yang semakin ketat (Pikiran Rakyat, 2016). Realitas ini diperkuat dengan hasil penelitian pendahuluan yang dilakukan pada Badan Pelayanan Perizinan Terpadu dan Penanaman Modal Kabupaten Cianjur, dimana cenderung lamban dan berbelit-belit dalam pelayanan sering terjadi. Masyarakat dihadapkan pada beberapa tahapan dengan harus melewati beberapa meja aparat dari beberapa instansi yang berbeda.Kondisi ini tentu yang antara lain menyebabkan masyarakat merasa bahwa pelayanan izin di Kabupaten Cianjur belum sesuai dengan harapan publik. Masih adanya kesenjangan pelayanan yangcukup lebar dan pembiaran pada institusi publik, hal tersebut tidak linear dengan slogan yang didengungkan mengenai percepatan good governance khususnya pada Pemerintahan Daerah.

Permasalahan sebagaimanadipaparkan di atas diduga disebabkan oleh masih rendahnya kualitas pelayanan pada aspek kemudahan, aspek kecepatan, aspek ketepatan,dan aspek keamanan sebagaimana dirasakan dan diterima oleh masyarakat pengguna jasa. Oleh karenanya,isu konseptual yangdiangkat dalam penelitian ini adalah "Bagaimana Kualitas Pelayanan Izin Mendirikan Bangunan pada Badan Pelayanan Perizinan Terpadu dan Penanaman Modal Kabupaten Cianjur?”. Hal ini mendukung beberapa hasil penelitian yang telah dilakukan bahwa kinerja pelayanan dari organisasiorganisasi pelayanan publik masih jauh dari yang diharapkan oleh masyarakat.Berdasarkan latar belakang tersebut, tujuan penelitian inihendak mengkaji sejauhmana proses pelayanan bidang IMB dan pencapaian kualitas pelayanannya.

\section{B. METODE PENELITIAN}

Dalam penelitian ini penulis menggunakan metodologi penelitiandeskriptif-kualitatif.Hal ini sejalan dengan karakteristik objek penelitian. Metode penelitian deskriptif-kualitatif dipilih dalam penelitian ini untuk menggambarkan fenomena pelayanan Izin Mendirikan Bangunan yang berlangsung di BPPTPM Kabupaten Cianjur Jawa Barat menurut perspektif para pelaku baik para investor, masyarakat, maupun para aparat yang memberikan pelayanan.

Pendekatan penelitian kualitatif dilakukan mengingat bahwa data hanya dapat dipahami dan diungkap melalui persepsi dan interpretasi para pelaku yang sulit diukur secara kuantitatif sehingga pemaknaan yang tepat hanya dapat diberikan oleh orang yang terlibat dalam pelayanan perizinan pendirian bangunan sebagai fokus kajian. Selain itu dengan melakukan pendekatan kualitatif, dapat melahirkan empati peneliti untuk dapat mengadaptasi diri dengan beragam realitas dan dinamika kehidupan masyarakat dan investor yang mengajukan Izin Mendirikan Bangunan (IMB).

Metode pengumpulan data kualitatif dilakukan dengan cara wawancara terhadap informan dari pihak penyelenggara layanan IMB berjumlah 31 orang yang terdiri dari 1 orang penanggung jawab Instansi dengan jabatan Kepala BPPTPM Kabupaten Cianjur, 4 orang Kepala Sub Bagian, 5 orang staf senior, 5 orang staf surveyor lapangan non-PNS aparatur, dan 16 orang tenaga magang siswa SMK. Hasil wawancara lalu dianalisis dengan cara kategorisasi terkait kualitas pelayanan. Tahap berikutnya dilakukan metode peningkatan kualitas data dengan triangulasi data pada 31orang informan tersebut. Selanjutnya jawaban-jawaban dari 31orang informan tersebut dikonfirmasi kepada 31 orang responden yakni para pemohon izin bangunan dan calon investor di BPPTPM Kabupaten Cianjur. 


\section{KERANGKA TEORI}

\section{Pelayanan Publik}

Pelayanan publik adalah setiap aktivitas pelayanan yang dilakukan pemerintah, individu, organisasi, dan yang lainnya (the others) dalam rangka merespon tuntutan individu, kelompok, organisasi, dan yang lainnya (the others) yang bersinggungan dengan kepentingan keseluruhan populasi penduduk. Siapa yang melayani tidaklah penting, yang penting adalah apa dan bagaimana kepentingan keseluruhan populasi penduduk direspon aktor-aktor yang berpotensi menjadi pelayan publik (Alamsyah, 2011:357).

Pelayanan publik sebagai muara dari pelaksanaan good governance dan indikator kinerja pemerintah dalam rangka memenuhi hak kebutuhan publik, perlu dilengkapi dengan manajemen pelayanan yang optimal. Manajemen pelayanan pada dasarnya adalah upaya internal organisasi penyedia pelayanan publik untuk melakukan perbaikan secara terus menerus (continous improvement) terhadap kualitas pelayanan yang diberikan sesuai tuntutan perubahan yang terjadi, terutama dari lingkungan eksternal organisasi (Meiliana, 2011:32)

Lijan Poltak (2008) dalam Safitri dan Andari (2011:158) mengartikan pelayanan publik sebagai pemberi layanan (melayani) keperluan orang lain atau masyarakat yang mempunyai kepentingan pada organisasi itu sesuai dengan aturan pokok dan tata cara yang telah ditetapkan.

Pelayanan Publik menurut Moenir AS. (2008:27) pelayanan adalah serangkaian kegiatan yang berlangsung secara rutin dan berkesinambungan dalam masyarakat. Berdasarkan uraian tersebut dapat diartikan bahwa pelayanan secara reguler dan teratur dihadirkan kepada masyarakat sebagai user melalui proses kegiatan secara terstruktur dan sistematis.

Adapun pelayanan publik menurut Ivancevich, Lorenzi, Skinner dan Crosby (Ratminto dan Atik Septi Winarsih, 2010:2) menyatakan bahwa pelayanan adalah produk yang kasat mata (tidak dapat diraba) yang melibatkan usaha-usaha manusia dan menggunakan peralatan. Mengacu pada pendapat tersebut pelayanan dapat diartikan sebagai sesuatu yang tidak dapat dilihat akan tetapi dapat dirasakan dan melibatkan usaha-usaha manusia dan menggunakan peralatan.

Pelayanan publik sejatinya diharapkan oleh masyarakat pengguna layanan dalam bentuk dan deliveryyang prima dalam arti pelayanan yang mudah, cepat, tepat, dan aman ditandai oleh pelayanan yang tidak berbelit-belit, pelayanan yang well-informed, responsif, akomodatif, konsisten, dan adanya kepastian (waktu-biaya-hukum) dan tidak dijumpai pungutan tidak resmi. Penerapan prinsip pelayanan prima dalam metode dan prosedur.

Selanjutnya menurut KEPMENPAN No. 63 tahun 2003 tentang Standar Pelayanan Publik bahwa pelayanan publik adalah segala kegiatan pelayanan yang dilaksanakan oleh penyelenggaraanpelayanan publik sebagai upaya pemenuhan kebutuhan penerima pelayanan maupun pelaksanaan ketentuan peraturan perundang-undangan.

\section{Konsep Kualitas Pelayanan}

Kualitas pelayanan merupakan fokus utama kajian pelayanan publik kontemporer seiring tuntutan publik akan hadirnya pelayanan yang semakin baik. Pelayanan dianggap berkualitas apabila tidak menimbulkan keluhan dari masyarakat yang dilayaninya. Kualitas pelayanan itu sendiri sangat terkait dengan konsep kepuasan pelanggan (Customer satisfaction).

Lukman (2000) dalam Ahmad (2015:115) menyebutkan bahwa kualitas yang diharapkan pengguna layanan terdiri dari sejumlah keistimewaan produk, baik keistimewaan langsung maupun keistimewaan atraktif yang memenuhi keinginan pelanggan dan dengan demikian memberikan 
kepuasan atas penggunaan produk.Dalam Manajemen Kinerja sektor Publik kualitas pelayanan dipengaruhi antara lain: (1) kecepatan pelayanan; (2) kebersihan, kerapian staf, dan fasilitas; (3) Keramahan dan kesabaran staf dalam melayani; (4) staf yang membantu dan bersahabat serta perhatian pada pelanggan; dan (5) keamanan dan kenyamanan (Susila, 2010:64)

Salah satu tugas pemerintah adalah memberi pelayanan. Dalam konteks tersebut pemerintah adalah pihak yang memproduksi, mendistribusikan, atau menjual alat pemenuhan kebutuhan rakyat yang berbentuk jasa publik, dan layanan sipil. Dalam hal ini, pemerintah memiliki kewajiban untuk memberikan pelayanan yang sebaik-baiknya, mengingat pelayanan yang baik merupakan bentuk deviden yang harus diterima masyarakat. Oleh karena itu, dalam melaksanakan tugas dan kewajibannya, aparatur/pegawai diharapkan menempatkan dirinya sebagai pelayan masyarakat dan bukan sebaliknya. Sebab dalam kaitannya dengan hal tersebut, kedua belah pihak memiliki posisi dan kewajiban yang sama, yaitu memerintah dan yang diperintah. Sejatinya kegiatan pelayanan masyarakat dalam prosesnya, terjadi interaksi antara memberi pelayanan dengan yang diberi pelayanan.

Konsep kualitas pelayanan mengandung banyak definisi. Menurut Ndraha (2007:83) mendefinisikan bahwa kualitas (quality) adalah characteristics, property, or attitude, character or nature. Definisi tersebut mengandung makna bahwa setiap hal atau barang mempunyai kualitas yang berbeda dengan yang lainnya. Kualitas berbeda value atau nilai. Nilai adalah guna, manfaat atau sesuatu yang diharapkan dari sesuatu hal pada suatu saat. Terdapat 3 (tiga) nilai sebagaimana yang dijelaskan Ndraha (2007) yakni: pertama nilai intrinsik yang melekat pada setiap benda yang bersifat obyektif, kedua, nilai eksentrik yang dimasukkan manusia kedalam suatu bendabersifat subyektif, dan yang ketiga adalah nilai ideal yang belum menjadi kenyataan. Nilai intrinsik dianggap given,sedangkan nilai ideal bersifat tidak nyata, abstrak, tidak empirik dan lebih berupa sebagai kekuatan penggerak manusia atau roda organisasi.

Pada tataran implementasinya, hal yang mengkhawatirkan dari konsep ideal pelayanan publik masih jauh dari harapan masyarakat pengguna layanan. Buruknya layanan publik mencerminkan masih adanya kesenjangan antara persepsi penyelenggara layanan dengan masyarakat penerima layanan hal mana disebabkan oleh beberapa faktor baik yang sudah banyak diketahui melalui penelitian-penelitian maupun yang masih diungkap akar masalahnya.

Parasuraman dkk. (1990:23) mengatakan bahwa ada 4 (empat) jurang pemisah/kesenjangan yang menjadi kendala dalam pelayanan publik, yaitu sebagai berikut:

1. Tidak tahu apa yang sebenarnya diharapkan masyarakat;

2. Pemberian ukuran yang salah dalam pelayanan masyarakat;

3. Penyampaian pelayanan yang salah dalam pelayanan publik;

4. Ketidakterpenuhan janji pelayanan.

Kesenjangan kualitas pelayanan publik dapat diketahui dengan cara membandingkan persepsi para pelanggan (masyarakat) dengan kenyataan pelayanan yang mereka terima. Apabila pelayanan dalam prakteknya yang diterima masyarakat tidak sesuai dengan harapan atau keinginan mereka, maka dapat dikatakan telah terjadi kesenjangan.

Menurut Zeithaml, et al. (1990:36-37) mengemukakan terdapat empat faktor yang mempengaruhi harapan (kepuasan) si konsumen yakni :

1. Word-of-mounth communication, yaitu apa yang didengar dari konsumen lain melalui komunikasi dari mulut ke mulut, hal ini merupakan faktor yang sangat potensial dalam mempengaruhi konsumen, konsumen akan memberikan saran atau menginformasikan pada konsumen lain tentang pelayanan yang didapatkannya. 
2. Personal needs, yaitu kebutuhan individu yang sangat tergantung terhadap karakteristik individu demikian juga terhadap situasi dan kondisi yang ada sehingga setiap konsumen memiliki kebutuhan yang berbeda terhadap pelayanan yang dibutuhkannya.

3. Past Experience, yaitu pengalaman di masa lampau juga mempengaruhi terhadap tingkatan harapan yang diinginkan konsumen. Apabila konsumen terbiasa dengan mendapatkan pelayananpelayanan yang memuaskan maka dia akan mengharapkan pelayanan minimal seperti yang pernah dioterima bahkan lebih berkualitas lagi.

4. External communication from the service provider,yaitu komunikasi eksternal yang diberikan oleh pemberi layanan baik secara langsung maupun tidak langsung, secara langsung melalui promosi, iklan dan tampilan-tampilan lain yang memberikan harapan akan pemenuhan kebutuhan konsumen.

Terkait dengan sejauhmana pemerintah sebagai penyelenggara layanan publik memiliki persepsi untuk meningkatkan kualitas layanannya, Zeithaml, et.al.(1990:72) mengemukakan bahwa kepuasan pelanggan adalah persepsi pelanggan atas suatu layanan yang dialaminya. Tanpa bermaksud untuk mengabaikan sistem dan berbagai faktor lainnya yang mempengaruhi kualitas pelayanan umum, faktor manusia dan organisasi dianggap sangat menentukan dalam menghasilkan pelayanan yang berkualitas. Sumber daya manusia merupakan faktor yang menentukan arah dan proses pelayanan. Oleh sebab itu, kualitas suatu pelayanantentu tergantung pada kondisi sumber daya manusia tersebut. Semakin berkualitas sumber daya manusia dalam organisasi penyelenggara pelayanan, maka dengan sendirinya kualitas pelayananpun semakin tinggi, dan bila terjadi sebaliknya maka kualitas pelayanan akan menurun.

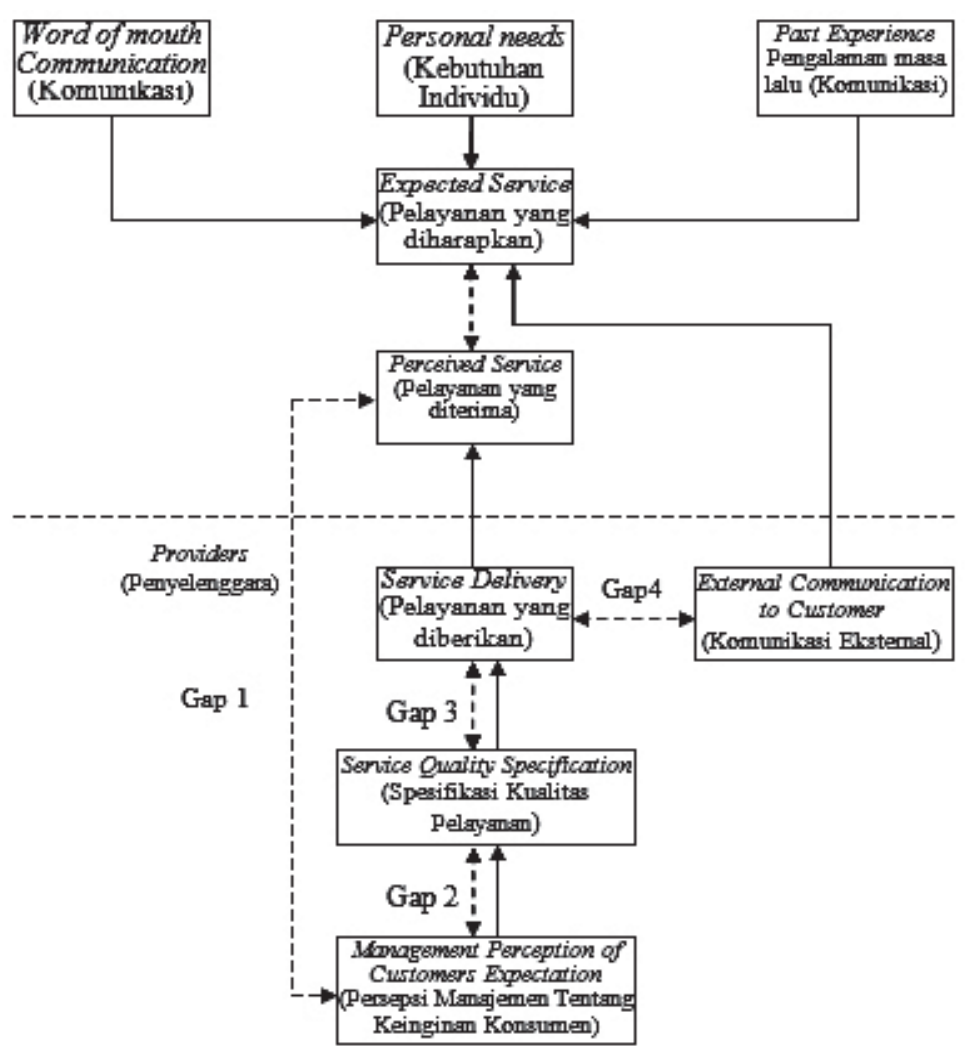

(Sumber : Zeithaml, et.al.1990 : 46).

Gambar 1.

Konsep Model Kualitas Pelayanan

(The Conceptual Model of Service QualityCustomers (Konsumen) 
Dengan demikian, kualitas pelayanan dapat dianalisis atas dasar indikator-indikator tersebut, yakni bahwa pelayanan harus bersifat nyata secara fisik dapat dilihat jelas fasilitas dan peralatan yang digunakan, personil yang menangani pelayanan, alat-alat komunikasi yang dipakai, serta hasilnya dapat dirasakan. Pelayanan yang berkualitas hanya dapat dipercaya dalam memenuhi standar pelayanan yang dijanjikan secara handal dan akurat, pelayanan yang berkualitas harus membantu pengguna layanan dan memberikan layanan secara cepat, pelayanan yang berkualitas juga harus memberikan jaminan bahwa kinerja pelayanan dilaksanakan oleh personil berpengetahuan luas, ramah, handal, terpercaya, dan keamanannya terjamin. Pelayanan yang berkualitas juga harus dapat memperhatikan kepentingan pengguna layanan secara individu.

Pelayanan perizinan menurut Raminto dan Winarsih (2006) dalam Sitorus (2009:1534) adalah segala bentuk jasa pelayanan yang pada prinsipnya menjadi tanggung jawab dan dilaksanakan oleh instansi pemerintah baik dalam rangka upaya pemenuhan kebutuhan masyarakat maupun dalam rangka pelaksanaan ketentuan peraturan perundang-undangan yang bentuk produk layanannya adalah izin atau warkat. Karena itu, civil service masuk ke dalam lokus administrasi negara. Selanjutnya, mengacu kepada pendapat Ndraha (2007:71) mengenai kualitas pelayanan direfleksikan oleh aspek kemudahan, kecepatan, ketepatan,dan keamanan yang selanjutnya dijadikan teori panduan dalam penelitian ini.

\section{HASIL DAN PEMBAHASAN}

\section{Aspek Kemudahan dalam Pelayanan IMB}

Kemudahan dalampelayanan publik yang dirasakan masyarakat salah satu cermin pelayanan publik yang berkualitas di tingkat unit layanan khususnya bidang perizinan kini merupakan obsesi dan tantangan yang harus segera diwujudkan oleh pemerintah daerah. Dengan adanya kewenangan yang lebih besar yang didelegasikan kepada pemerintah daerah melalui otonomi daerah menerbitkan harapan besar bagi terwujudnya program-program pelayanan publik yang lebih baik, termasuk pelayanan Izin Mendirikan Bangunan (IMB).

Kemudahan dalam konteks pelayanan pada BPPTPM Kabupaten Cianjur berdasarkan pendapat Ndraha (2007) mencakup 3 (tiga) indikator. Selanjutnya melalui kuesioner yang diberikan kepada masyarakat pengguna jasa, peneliti mengukur sejauh mana kemudahan diberikan dengan cara pemberian tanggapan tertulis dan seterusnya. Hasil penilaian masyarakat yang mencakup aspek kemudahan, kesesuaian persyaratan, kecepatan, ketepatan dan aspek-aspek pelayanan lainnya berada pada nilai kategori bawah. Hal ini mencerminkan bahwa manajemen belum maksimal dalam memenuhi harapan masyarakat. Skor kesenjangan yang mencapai nilai cukup lebar dikarenakan ada dua unsur yang paling mengecewakan masyarakat yaitu kesulitan dan ketepatan waktu penyelesaian dokumen.

Dari 31 responden dari masyarakat pemohon izin pendirian bangunan pada BРPТРM Kabupaten Cianjur, tercatat 24 orang diantaranya menyatakan bahwa para aparatur perizinan memberikan pelayanan melalui beberapa tahapan atau beberapa saluran (prosedur), dan terkait disposisi Instansi lain di luar BPPTPM yang dinilai masyarakat menjadikan pelayanan berbelit-belit dan memakan waktu yang lama dari yang ditetapkan. 


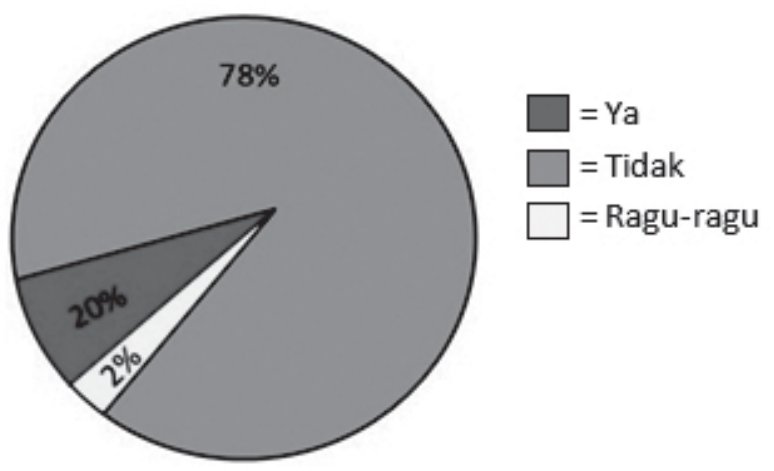

Gambar 2.

Kemudahan PelayananPetugas BPPTPM Kab. Cianjur

Menurut Ndraha (2007) kemudahan dalam pemberian pelayanan bermakna bahwa masyarakat menginginkanpelayanan publik yang disediakan oleh pemerintah mudah diperoleh dan dijangkau dari segi jarak, waktu dan biaya. Kemudahan pelayanan IMB mengandung arti masyarakat mudah mengakses informasiyang disediakan melalui website BPPTPM Kabupaten Cianjur namun ada pengakuan pada tataran teknis operasional adanya keterbatasan karena tidak semua informasi dapat diakses pada web tersebut, kurangnya media informasi mengenai perizinan, peralatan pendukung pelayanan (seperti komputer, mesin antrian, pendingin ruangan) dalam kondisi rusak sehingga juga berimbas pada pelayanan yang diberikan. Ketersediaan sarana dan prasarana merupakan penunjang utama kegiatan organisasi dan berperan penting dalam menjaga mutu pelayanan (Ningsih, Alam, dan Najmi, 2015:67). Komunikasi staf kepada pimpinannya dirasakan oleh pengguna jasa perizinan kurang efektif dengan skor kesenjangan yang cukup lebar.

Adapun faktor-faktor penghambat yang ditemukan dalam mewujudkan kemudahan dalam mengurus IMB adalah antara lain daya dukung infrastruktur kantor yang belum memadai, sarana kerja bidang administrasi mencakup juga peralatan kerja yang masih manual dan sederhana. Formulir pengurusan IMB yang tersedia masih terbatas hal ini disebabkan disediakan juga oleh instansi lain(Dinas Permukiman) serta SKPD lainnya.

Tabel 2.

Rekapitulasi IMB Tahun 2015

\begin{tabular}{|l|c|c|}
\hline \multicolumn{1}{|c|}{ Jenis IMB } & Izin yang Masuk & Izin yang Keluar \\
\hline Rumah Tinggal & 309 & 265 \\
\hline Villa & 411 & 350 \\
\hline Ruang Usaha & 334 & 212 \\
\hline Perumahan & 234 & 102 \\
\hline Perkantoran & 157 & 132 \\
\hline
\end{tabular}

Sumber:BPPTM, 2017 (diolah)

Kemudahan pelayanan menjadi kontradiktif atau bahkan sulit terwujud manakala dalam beberapa kasus disebabkan oleh sikap masyarakat pengguna jasa yang mencoba jalur cepat atau memotong jalur antrian dengan upaya memberikan insentif kepada oknum pegawai BPPTPM yang menyalahi aturan. Pelayanan perizinan dengan demikian harus mengacu kepada standar tertentu yang merupakan spesifikasi teknis atau sesuatu yang telah dibakukan sebagai patokan dalam melakukan kegiatan dalam hal ini pelayanan perizinan. 


\section{Aspek Kecepatan dalam Pelayanan IMB}

Aspek kecepatan dalam pelayanan IMB dapat diukur melalui beberapa indikator:1) Dalam waktu singkat dapat memberikan pelayanan; 2) Pencapaian tepat waktu dalam pelayanan; 3) Kemandirian kerja; 4) Antisipatif dalam perubahan pelayanan; 5) Responsif dalam pelayanan; dan 6) Segera memberi informasi kepada pelanggan.

Tanggapan para informan pada aspek kecepatan pelayanan IMB umumnya menyatakan sikap tanggap para pegawai BPPTPM dalam perizinan IMB sudah baik dari segi sopan santun dan segera memberikan formulir yang harus diisi oleh pemohon. Namun, pemohon lebih mengharapkan berkurangnya kerumitan melalui berkurangnya tahapan meja yang harus dilalui dalam pengurusan perizinan, namun demikian sikap responsif pegawai telah dihargai.

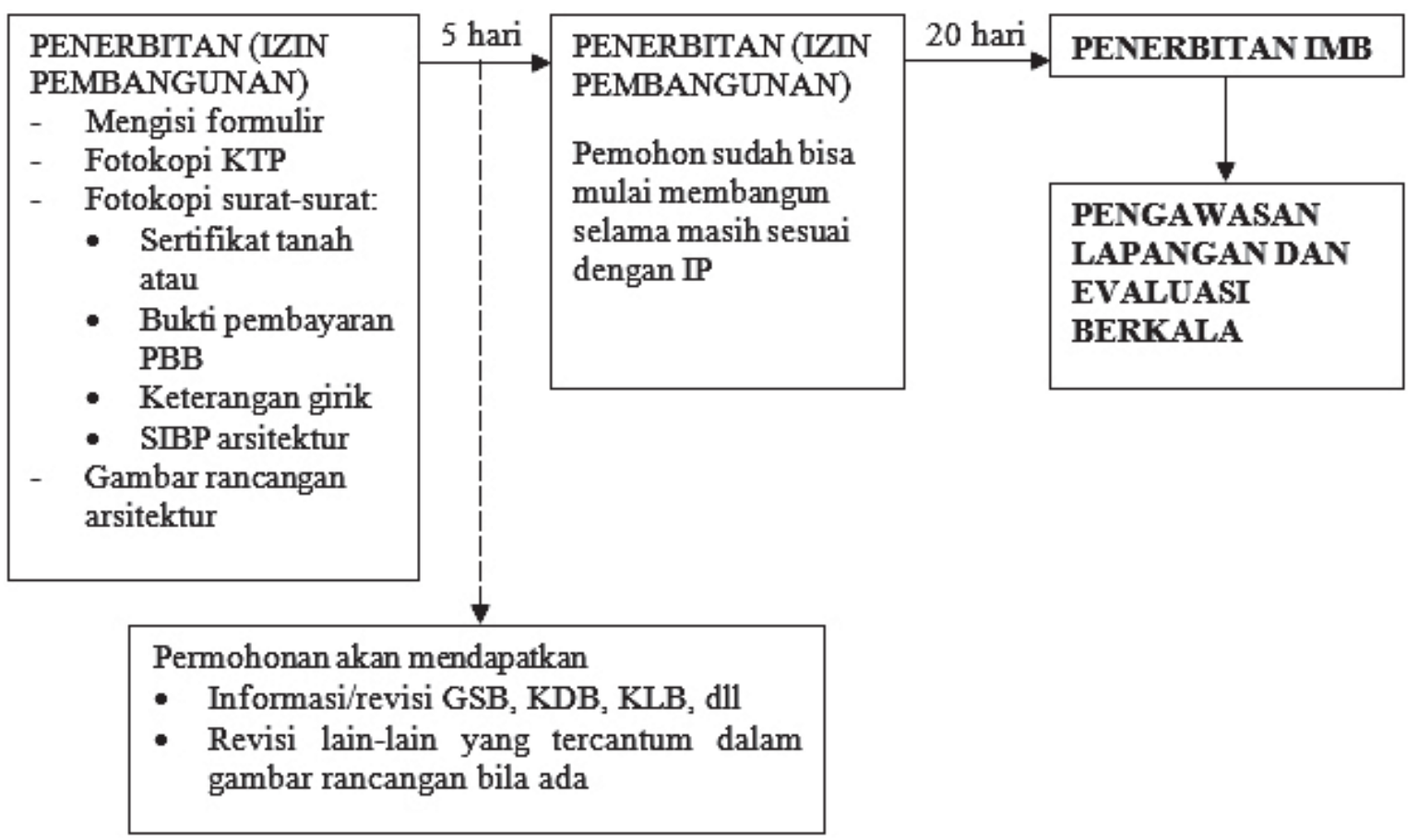

Gambar 3.

Skema Tahapan IMB

Harapan masyarakat yang dilayaninya adalah penting untuk diwujudkan, tetapi hal itu saja tidaklah cukup untuk mewujudkan suatu tingkat pelayanan yang paripurna pada kondisi masyarakat seperti sekarang ini. Untuk mencapai itu diperlukan pra-syarat lain yaitu beberapa keberadaan standar kerja atau performa mencerminkan persepsi manajemen yang memahami harapan masyarakat. Namun pada kenyataannya, secara empirik berdasarkan hasil wawancara pada sebagian besar para pejabat penyelenggara layanan izin pendirian bangunan (IMB) mayoritas mengalami kesulitan dalam menterjemahkan (translating) pemahaman mereka (para pejabat) tentang harapan masyarakat ke dalam bentuk daftar perincian spesifikasi kualitas pelayanan. 


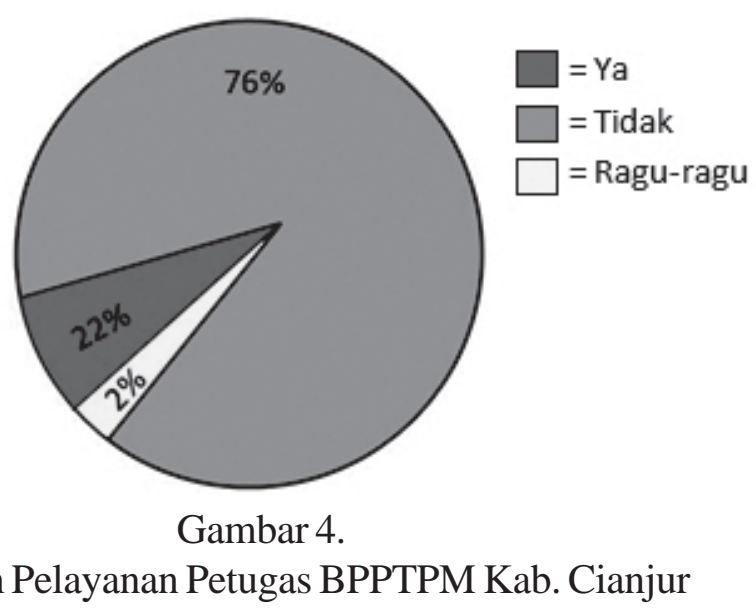

Dari 31 responden dari masyarakat pemohon izin pendirian bangunan pada BPPTPM Kabupaten Cianjur, tercatat 24 orang diantaranya menyatakan bahwa para aparatur perizinan memberikan pelayanan tidak merata sesuai target waktu yang ditetapkan, pada tahap finishing yang seharunya 20 hari bisa molor menjadi beberapa bulan yang dinilai masyarakat menjadikan pelayanan sangat lamban memakan waktu yang lama dari yang ditetapkan.

Dari sisi kemandirian pegawai yang berhubungan langsung dengan pelanggan dinilai masih rendah. Hasil analisis menunjukkan bahwa pegawai masih belum mampu bekerja sendiri tanpa melakukan kesalahan. Pegawai masih mempunyai self interest dalam pelayanan berupa penerimaan insentif diluar ketentuan. Bagi masyarakat aspek kecepatan lebih dipahami sebagai ekspektasi standar pelayanan dari BPPTPM sebagai institusi. Berdasarkan pengamatan di lapangan hal yang paling menonjol yakni terdapat ketidaksesuaian antara prosedur pelayanan dengan operasionalisasi yang senyatanya. Persyaratan berkas permohonan seringkali menjadi hambatan dalam pemrosesan waktu perizinan.

Adapun faktor-faktor penghambat yang ditemukan dalam mewujudkan kecepatan dalam mengurus IMB adalah antara lain struktur organisasi yang belum solid dalam arti masih adanya tumpang tindih pekerjaan yang dikerjakan oleh beberapa bagian, disposisi untuk terbitnya sertifikat IMB menjadi kewenangan Instansi lain. Kondisi demikian secara tidak langsung menciptakan prosedur pelayanan menjadi tambah rumit dan sulit diurai untuk disederhanakan (job simplification).

\section{Aspek Ketepatan dalam Pelayanan IMB}

Menurut pendapat Ndraha (2007), ketepatan dalam pelayanan merupakan aspek kualitas pelayanankepada masyarakat yang berkaitan dengan pemenuhan janji dan kewajiban. Tujuan yang ingin dicapai, sasaran atau objek yang menjadi fokus perhatian, keinginan atau kepentingan yang ingin diperoleh, prosedur yang dilalui, maupun waktu yang dibutuhkan dalam pelayanan. Ketepatan pelayanan mengandung arti layanan yang diberikan aparatur kepada masyarakat haruslah tepat,atau persis tidak kurang dan tidak lebih sesuai dengan janji yang wajib dipenuhi. Sesuai dengan pengamatan pada proses pelayanan adanya ketidaktepatan pelayanan yang terjadi oleh karena faktor antara lain: adanya keragu-raguan pegawai untuk memuaskan harapan pimpinan, munculnya role conflict dalam diri pegawai, ketidaksesuaian penempatan pegawai dan ketidaksesuaian teknologi yang digunakan dalam mendukung pelayanan, tidak adanya sistem evaluasi serta persepsi pegawai terhadap fleksibilitas tindakan dalam memberikan pelayanan dan tidak adanya kerjasama pegawai dan pimpinan organisasi dalam memberikan pelayanan. 
Dari 31 responden dari masyarakat pemohon izin pendirian bangunan pada BРPТРM Kabupaten Cianjur, tercatat 26 orang diantaranya menyatakan bahwa para aparatur perizinan yang memberikan pelayanan belum akurat baik secara administratif maupun non administratif, adanya keragu-raguan sebagian staf dalam menangani urusan-urusan yang terkait dengan dokumen-dokumen penunjang persyaratan. Hal itu dipertegas oleh sumber daya manusia yang masih timpang baik kuantitas maupun kualitasnya dan terkait dengan daya dukung peralatan kerja yang belum memadai dan terkesan out of date.

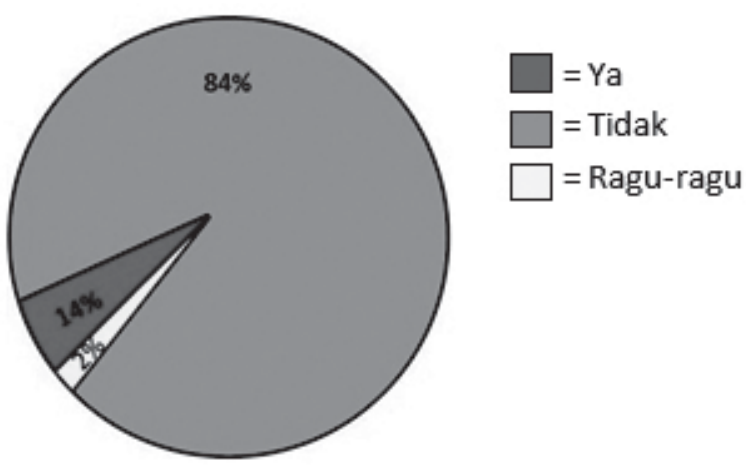

Gambar 5.

Ketepatan Pelayanan Petugas BPPTPM Kab. Cianjur

Pada umumnya hasil wawancara para pejabat pelayanan publik perizinan pada BPPTPM Kabupaten Cianjur memberikan tanggapan berupa asumsi penyebab rendahnya pelayanan yang diberikan dengan merujuk pada ketidaktulusan (unwillingness) dan ketidakmampuan (inability) para petugas lini depan dalam melayani para pengguna jasa, karena peran petugas lini depanlah yang sangat krusial dalam memenuhi tuntutan mekanisme kerja yang telah ditetapkan, memperbaiki pelayanan izin bangunan (IMB) tidaklah mudah karena memerlukan syarat untuk memperbaiki para personel lini depan, baik pada bidang administrasi maupun bidang survey lapangan.

Berdasarkan hasil penelitian, terdapat beberapa faktor penyebab yang menentukan terjadinya ketidaktepatan pada ranah spesifikasi kualitas pelayanan dan dalam konteks penelitian pelayanan perizinan bangunan (IMB) di BPPTPM Kabupaten Cianjur dapat dideskripsikan sebagai berikut :

- Pencapaian ketepatan pada aspek spesifikasi layanan merupakan titik kritis dari ketiga aspek penyelenggaraan layanan yang terjadi pada pelayanan izin mendirikan bangunan(IMB). Hasil pengamatan pada aspek ketepatan layanan menunjukkan tingkat kesenjangan yang masih lebar. Kesenjangan yang paling lebar pada ketidaksesuaian pelayanancukup signifikan berdasarkan wawancara dengan masyarakat hal ini terjadi ketika mereka ditangani oleh pegawai belum pengalaman dan oleh para trainee sehingga sering terjadi maladministrasi. Demikian juga pada aspek kesiapan petugas, keraguan pegawai masih nampak ketika merespon situasi menekan sehingga masyarakat memberikan penilaianyang cukup kecildan pada sisi manajemen cukup permisif dengan penilaian besar. Pada aspek kesesuaian standar biaya terlihat kesenjangan masih cukup tinggi bentuk refleksi masyarakat pengguna jasa layanan perizinan merasakan insentif yang harus dikeluarkan diluar biaya resmi kepada pegawai dengan pemberian rata-rata tanggapan hasil wawancara yang rendah yaitu pada indikator itu. Pada keadaan sebaliknya manajemen tidak mencermati lingkungan interaksi pegawai dan memandang kesesuaian pelayanan pegawai cukup baik.

- Kesenjangan yang terdapat pada indikator ketidaksesuaian teknologi sesuai yang terekam di lapangan masih menunjukkan peran daya dukung perangkat teknologi dan aplikasi sistem 
informasi belum optimal memperlancar pelayanan perizinan.Indikator-indikator kesesuaian penempatan pegawai, sistem pengawasan, dan persepsi masih dalam kelompok kesenjangan lebardimana perlu upaya-upaya perbaikan dalam melayani, memproses, pengajuan izin dan secara langsung dirasakan oleh masyarakat pengguna jasa sehingga skor kesenjangannya makin bisa mengecil secara bertahap.

- Adanya perbedaan pandangan secara empirik antara petugas pemberi layanan dan masyarakat penerima layanan dalam konteks aspek ketepatan pelayanan perizinan IMB sebagaimana diuraikan diatas dapat dimaknai bahwa terdapat kesenjangan persepsi antara manajemen dengan persepsi pelanggan.

\section{Aspek Keamanan dalam Pelayanan IMB}

Keamananpelayanan merupakan terjaminnya kondisi tingkat keamanan lingkungan unit penyelenggaraan pelayanan ataupun sarana yang digunakan sehingga masyarakat merasa senang untuk mendapatkan pelayanan terhadap risiko-risiko yang diakibatkan dari pelaksanaan pelayanan.Mencakup rasa aman dari bahaya, risiko atau keragu-raguan terhadap berbagai aspek yang dibutuhkan pelanggan seperti keamanan fisik, keamanan finansial dan kerahasiaan. Pada sisi lain faktor determinasi dari harapan eksternal yang memadai dan kredibel keamanan pelayanan dalam konteks layanan publik dapat dimaknai berupa spesifikasi layanan yang sederhana, terukur dan komponen biaya yang terjangkau.

Keamananpelayanan dalam konteks pelayanan perizinan bangunan (IMB) dapat diketahui pada beberapa prosedur pelayanan yang dipampang terbuka pada lobbyBPPTPM, brosur BPPTPM, display pelayanan dan penjelasan-penjelasan menyangkut mekanisme pelayanan oleh para pegawai lini depan. Kesenjangan komunikasi eksternal ini dapat mendorong terciptanya kesan pada diri masyarakat pengguna jasa terhadap keseluruhan kualitas pelayanan.

Untuk mengukur sejauhmana kepastian pelayanan BPPTPM dapat dirasakan masyarakat pengguna jasa, cuplikan hasil wawancara terhadap seorang investor yang menyatakan tertarik memulai usaha di bidang perhotelanberskala kecil dengan asumsi pengajuan IMB-nya tidak merepotkan karena tanah tersebut milik keluarga dalam bentuk warisan orang tuanya.Namun,ternyata setelah ditempuh banyak sekali persyaratan yang harus dipenuhi dan melewati beberapa meja. Harus adanya izinBupati atas lahan yang akan digunakan, setelah izin Bupati keluar masih belum juga IMB-nya keluar dengan alasan harus ada izin pendukung dari instansi BPLHD, dan belum izin-izin yang lainnya sehingg sepertinya pemerintah daerah kurang ramah terhadap usahawan kecil. Rasa aman dalam pelayanan perizinan juga tidak terlepas dari segi kepastian biaya perizinan yang ditimbulkannya, dimana relatif masih dapat terjangkau oleh kemampuan masyarakat pengguna jasa, bahkan tentu sesuai hasil wawancara pada umumnya masyarakat yang sedang memproses IMB mereka menginginkan dibebaskannya dari biaya administrasi tersebut.

Indikator penting dalam aspek keamanan adalah adanya kepastian hukum(legal aspect).Jaminan kepastian hukum merupakan aspek krusial seseorangyang sering muncul dikemudian hari ketika keabsahan sertifikat IMB dipertanyakan. Sering terjadi fenomena di masyarakat gugatan bahkan diajukan terhadap kepemilikan tanah yang sudah bersertifikat dimana dari 31 responden yang memiliki IMB, 6 orang dalam proses tergugat status IMB nya, hal ini menandakan keamanan suatu produk hukum berupa sertifikat tanah masih belum aman, untuk itu dalam proses sertifikasi bangunan harus dimulai dengan proses pengajuan IMB secara benar. 


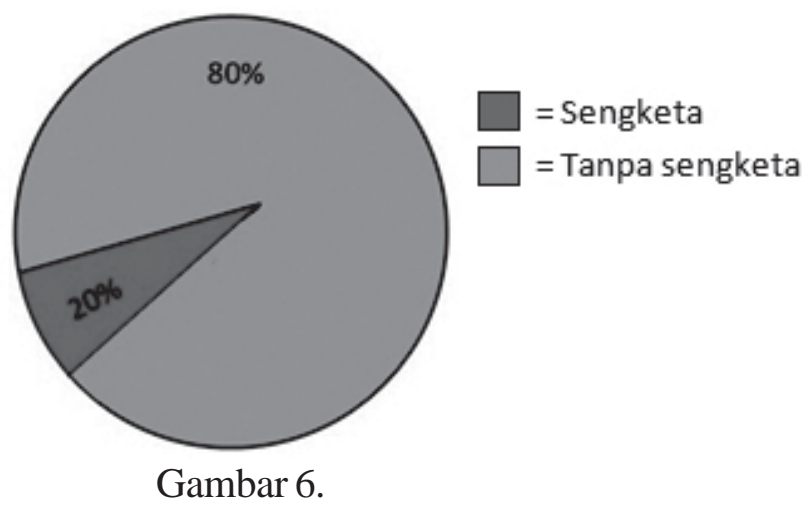

Kualitas Pelayanan Petugas BPPTPM Kab. CianjurPada Aspek Keamanan

Indikator lain adalah rasa aman secara fisik di lingkungan BPPTPM termasuk didalamnya keamanan parkir kendaraan, keamanan pelayanan dari gangguan calo, pedagang asongan dan sejenisnya. Keamanan pelayanan juga berkaitan dengan hal pokok yakni fungsi regulasi pemerintah yang berkorelasi dengan fungsi pengawasan dalam perizinan. Bahwa izin adalah sebuah konsesi yang diberikan pemerintah untuk mendirikan bangunan untuk itu pemerintah harus bertanggung jawab dan turut menjaga keamanan dan kelestarian lingkungan hidup, keamanan dan estetika bangunan terhadap penghuninya dan lingkungan sekitarnya. Keamanan dalam pelayanan publik diartikan sebagai adanya proses dan produk hasil pelayanan yang dapat memberikan keamanan, kenyamanan dan kepastian hukum bagi masyarakat (Monoarfa, 2012).

Dari keempat aspek kualitas pelayanan yang telah diuraikan berdasarkan hasil penelitian dapat dikemukakan bahwa aspek pelayanan 3 (tiga) yaitu ketepatan dalam penyelenggara pelayanan merupakan aspek pelayanan yang paling timpang dirasakan oleh para pengguna jasa pelayanan perizinan pendirian bangunan (IMB). Kemudian aspek kemudahan sebagai janji pelayanan yang belum terpenuhi, selanjutnya berurutan aspek kecepatan pelayanan dan keamanan pada penyelenggaraan layanan.

Hasil penelitian menunjukkan keluhan-keluhan masyarakat pengguna jasasebagian besar merupakan cerminan kelemahan-kelemahan tata laksana penyelenggaraan pelayanan, hanya sebagian kecil merupakankebiasaan buruk masyarakat pengguna jasa yang mencoba mengintervensi birokrasi pelayanan maka birokrasi pelayanan publik perlu menyusun daftar inventori masalah pelayanan perizinanyang berulang-ulang terjadi dan belum terpecahkankemudian tindakan pemecahan masalah dan selanjutnyabertransformasi membentuk tata layanan yang efektif dan berorientasi friendly customer sebagai tantangan dalam konteks tatanan masyarakat pada era new public service sebagai bagian dari kebutuhan peri kehidupan masyarakat dewasa ini.

\section{Faktor Kendala Hadirnya (Delivery) Pelayanan Berkualitas}

Faktor-faktor penyebab utama yang menghambat BPPTPM kabupaten Cianjur dalam menghadirkan pelayanan kepada masyarakat adalah struktur organisasi yang belum solid masih adanya tumpang tindih (overlapping) pekerjaan yang dikerjakan oleh beberapa bagian. Masyarakat pemohon izin juga memandang bahwa seharusnya tahapan perizinan sampai dengan terbitnya produk organisasi BPPTPM yang berupa sertifikat IMB dapat tuntas di BPPTPM, tidak sebaliknya harus menempuh prosedur terkait disposisi instansi lain yakni Dinas Bangunan dan Tata Ruang Kabupaten Cianjur yang mempunyai wewenang untuk hal itu. Kondisi demikian secara tidak langsung menciptakan prosedur pelayanan menjadi tambah rumit dan sulit diurai untuk disederhanakan (job simplification). 
Faktor infrastruktur dan teknologi perkantoran berdasarkan pengamatan langsung yang terekam di lapangan belum memadai, sarana kerja bidang administrasi tidak didukung perangkat komputer yang cukup dan aplikasi yang tidak updatesehinggasebagian besar pekerjaan dilakukan secara manual. Belum adanya perangkat teknologi (integrated website)untuk melayani pendaftar dari tempat yang jauh dari pusat kota juga menjadi kendala,hal ini sebagaimana yang disampaikan seorang pemohon izin pendirian usaha ikan tangkap dari pesisir Cidaun Cianjur Selatan: "Saya berharap sekali ada cara yang membantu pemohon izin usaha sekedar pendaftaran tidak usah datang langsung ke BPPTPM yang ada di Kota Cianjur, jarak dari sini sangat jauh. Sekarang zaman teknologi serba mudah dan cepat.”

Terkait ketimpangan SDM adanya kenyataan jumlah pegawai yang terbatas yakni hanya ada 5 (lima) pegawai PNS yang berkualifikasi dan kompeten bidang perizinan dan sisanya bergantung pada tenaga honorer juga tenaga magang(trainee) dari sekolah-sekolah di wilayah Kabupaten Cianjur. Akibatnya, pelayanan urusan-urusan dokumen persyaratan perizinan sering kali dihadapi secara ragu-ragu dan salah prosedur (maladministration)sehingga pelayanan tidak akurat baik secara administrasi maupun non-administrasi. Padahal petugas pelaksana pelayanan harus memiliki pengetahuan, keterampilan, keahlian, serta pengalaman dalam menjalankan pekerjaannya agar pelayanan yang diberikan bermutu (Ma’dika, Halim, dan Alam, 2016:56)

\section{E. PENUTUP}

\section{Kesimpulan}

Berdasarkan hasil analisis terhadap keempat aspek pelayanan yaituaspekkecepatan, aspek kemudahan, aspekketepatan, dan aspek keamananmenggambarkan kualitas pelayanan BPPTPM dalam memproses dan menerbitkan izin pendirian bangunan (IMB) belum berjalan dengan baik serta belum mengutamakan persepsi pelanggan dan ditandai masih adanya beberapa kelemahan dalam pelaksanaannya. Adapun kendala-kendala yang dihadapi dalam penyampaian pelayanan yang berkualitas dihadapkan pada persoalan antara lain struktur organisasi BPPTPM yang belum solid, ketimpangan sumber daya manusia baik kuantitatif maupun kualitatif,daya dukung infrastruktur dan teknologi perkantoran yang kurang memadai dan tidak up to date, dan ketidaksederhanaan prosedur yang belum terurai.

\section{Rekomendasi}

1. Pemerintah perlu membuat suatu standar yang menjadi panduan bagi pejabat pelayanan dalam pelaksanaan tugas, termasuk sebagai guidance bagi masyarakat dalam memperoleh pelayanan perizinan.

2. ВРPТРM perlu didukung dengan komponen staf pendukung yang terlatih dan memiliki disiplin ilmu yang memadai.

3. Perlu adanya penyediaan infrastruktur yang memadai dan modern untuk menunjang tugastugas staf agar bisa lebih cepat dan tepat dalam memproses perizinan.

4. Perlu disusun road map untuk diaplikasikannya perizinan secara online, sehingga masyarakat yang mengajukan izin dapat diminimalisir untuk tidak bertemu langsung dengan petugas perizinan. 


\section{DAFTAR PUSTAKA}

Ahmad, Badu. (2015). Inovasi pelayanan perizinan di lingkungan pemerintah kota makassar. Jurnal Administrasi Publik, XI (2): 111-120

Alamsyah. (2011). Karakteristik Universal Pelayanan Publik: Sebuah Tinjauan Teoritik. Jurnal Borneo Administrator, 7 (3): 353-371

http://www.kabarcianjur.com/2016/mahalnya-biaya-perizinan-di-cianjur,diunduh tanggal 4 Pebruari 2017.

http://www.pikiran-rakyat.com/2016/cianjur-lebih-ketat-izinkan-vila-di-puncak,diunduh tanggal 6 Pebruari 2017.

Ma'dika, Karyawati, Halim, dan Alam Tauhid Syukur. (2016). Pemenuhan Standar Pelayanan Publik Bidang Administrasi Kependudukan pada Dinas Kependudukan dan Catatan Sipil Kabupaten Mamasa. Jurnal Administrasi Negara, 22 (2) : 49-58

Meiliana. (2011). Menyongsong Reformasi Birokrasi Tahap Kedua Melalui Peningkatan Kualitas Pelayanan Publik. Jurnal Borneo Administrator, 7 (1) : 24-44

Moenir, H.A.S. (2008). Manajemen Pelayanan Umum di Indonesia. Jakarta: Bumi Aksara.

Monoarfa, H. (2012). Efektivitas dan efisiensi penyelenggaraan pelayanan publik: Suatu tinjauan kinerja lembaga pemerintahan. Jurnal Pelangi Ilmu, 5(01).

Ndraha, Talidziduhu.(2007). Pengantar Teori Pengembangan Sumber Daya Manusia, Jakarta :PT. Rineka Cipta.

Ningsih, Fitriah, Alam Tauhid Syukur, dan Najmi Kamariah. (2015). Pendekatan Sistem dalam Menjaga Mutu Pelayanan Rawat Inap Sampuria Puenya Puskesmas Pandauke Kecamatan Mamosalato Kabupaten Morowali Utara. Jurnal Administrasi Negara, 21 (2) : 62-69 (2006).Budaya Pemerintahan dan Dampaknya Terhadap PelayananMasyarakat, Jakarta Jurnal Ilmu Pemerintahan Edisi ketiga.

Parasuraman, A., V. A. Zeithaml, dan L. L. Berry. (1990), “The Behavioral Consequences Of Service Quality”.Journal Of Marketing, Vol. 60 (2)

Peraturan Daerah Kabupaten Cianjur Nomor 14 Tahun 2012 tentang Retribusi IMB.

Ratminto, dan Atik Septi Winarsih. (2010). Manajemen Pelayanan. Yogyakarta:Pustaka Pelajar.

Safitri, Yudiantarti dan Andari, Rosita Novi. (2011). Best Practice Penyelenggaraan Pelayanan Publik Kecamatan (Studi Perbandingan Antara Kecamatan di Kabupaten Agam dan Kabupaten Bantul). Jurnal Borneo Administrator, 7 (2):154-176

Sitorus, Monang. (2009). Pengaruh Reliability, Responsiveness, Assurance, Empathy, dan Tangibles Terhadap Kualitas Pelayanan Publik (Studi Kasus Kantor Pelayanan Terpadu Kota Dumai). Jurnal Borneo Administrator, Vol 5, No. 1:1531-1547

Susila, L. N. (2010). Analisis Pengaruh Kualitas Pelayanan Kantor Kelurahan Terhadap Kepuasan Masyarakat Kelurahan Jagalan Kecamatan Jebres Kota Surakarta. Journal of Rural and Development, 1(1) : 63-72

Undang-Undang Nomor 25 Tahun 2009 tentang Pelayanan Publik.

Undang-Undang Nomor 23 Tahun 2014 tentang Pemerintahan Daerah. 
Zeitaml, Valarie A., Parasuraman, A., and Berry, Leonard L. (1990).DeliveringQuality Service (Balancing Customer Perceptions and Expectations).New York-Oxford-Sidney : The Free Press ADivision of Macmillan, Inc.

Zeithaml, Valarei A., Mary jo Bitnet. (2004).Service Marketing : IntegratingCustomer Focus Across The firm, $3^{\text {rd }}$ Ed., New York : McGraw-Hill. 